\title{
DYNAMICS AND OCCURENCE PATTERNS OF THE TATARIAN ORACHE ATRIPLEX TATARICA L. (CHENOPODIACEAE) AT THE ROADSIDES IN WARSAW, POLAND
}

\author{
INGEBORGA JARZYNA ${ }^{1}$, KATARZYNA MAŁECKA ${ }^{2}$, \\ DOROTA PANUFNIK-MĘDRZYCKA ${ }^{1}$, PIOTR MĘDRZYCKI ${ }^{3}$ \\ ${ }^{1}$ Department of Plant Ecology and Environment Protection, \\ Faculty of Biology, University of Warsaw \\ Al. Ujazdowskie 4, 00-478 Warszawa, Poland \\ e-mail: i.jarzyna@uw.edu.pl \\ University of Ecology and Management, \\ 2 Faculty of Architecture \\ ${ }^{3}$ Faculty of Ecology \\ Wawelska 14, 02-061 Warszawa, Poland
}

(Received: January 14, 2010. Accepted: April 15, 2010)

\begin{abstract}
Atriplex tatarica is an invasive annual plant from Central Asia. It is an early successional species of disturbed habitats, tolerant of a high content of $\mathrm{NaCl}$. It grows also by the roadsides, on lawns by the streets and other places in cities sprayed with salt during snowfalls. The paper presents results of the analysis of abundance and patterns of occurrence of this invasive subhalophytic plant by the roadsides in the Warsaw city. We found that frequency and distribution of Atriplex tatarica increased significantly over the last few decades. The species grows chiefly along main streets which are de-iced. It forms monodominant patches of different length at the zone closest to the street verge. The $\mathrm{NaCl}$ concentration there is significantly higher than in the zones more distant from the street verge, although this parameter is very variable. The cover of other species increases with an increasing distance from the roadside verge.
\end{abstract}

KEY WORDS: Atriplex tatarica L., invasive plant, urban roadsides, abundance, halophytic plant, plant competition.

\section{INTRODUCTION}

One of the groups of plants commonly entering cities are halophytes, plants with special salt adaptation mechanisms (Hasegawa et al. 2000). Wrobel et al. (2006) observed 34 species of halophytes (mainly Dactylis glomerata, Poa pratensis and Achillea millefolium) along roads within the Goleniów Primeval Forest and agricultural areas in Szczecin Lowland (North West Poland). Also Akbar et al. (2008) mentioned over a dozen halophytic species along roadside verges in Yorkshire, England.

Invasion by exotic plant species is often associated with change of soil properties (Gelbard and Belnap 2003; Haal and Surje 2006; Leung et al. 2009). Halophytic plant invasions may be the side effect of winter road maintenance. Roads are sprayed with mixtures of sand and chlorine salts during the snowfall. Melting snow, sand and salt are then removed and deposited on the roadside, where it infiltrate into the ground increasing the salinity of the topsoil. Increased salt concentration may limit growth of non halophytic plant species and enable the invasion of halophytes.
In Warsaw (Poland), one of the most common halophytes on the roadsides is Tatarian orache (Atriplex tatarica, Chenopodiaceae). It is an invasive, annual, early successional plant of disturbed habitats (Kochankova and Mandak 2008), where it often forms monodominant stands. It is intolerant to shade (Ungar 1996; Kochankova and Mandak 2008) and is tolerant to high contents of $\mathrm{NaCl}$ in soil (Mandak 2003). In its native range in Central Asia it occurs in saline and alkaline deserts, wet plains and field margins (eFloras 2009).

Tatarian orache was first found in Europe probably even before the year 1500 (Pysek et al. 2002). In Warsaw the species had been recorded in the first half of 19th century (Sudnik-Wójcikowska 1987) and is frequent in the city until now, growing at anthropogenic places, roadsides, lawns by the streets and waste lands. Sudnik-Wójcikowska (1987) suggests that it had increased its spread during last couple of decades.

The aim of the study was analysis of the distribution of Tatarian orache at the scale of the whole Warsaw city, in order to find general patterns of invasion since the last su- 
rveys in 1977-1982 (Sudnik-Wójcikowska 1987), and the analysis of abundance of the species along the gradient across the roadside in order to assess the influence of salinity and the distance from the road.

\section{METHODS}

We tested the following hypotheses:

- Hypothesis no. 1: Has Atriplex tatarica changed its spread in the city during last 30 years?

We supposed, that Tatarian orache, as an invasive species, had increased its coverage in the city and might not equally prefer central and peripheral districts of the city.

- Hypothesis no. 2: Does the mean of Atriplex tatarica cover on the roadside lawns depend on the distance from the road and does the salinity affect this dependence?

We supposed that Tatarian orache as a halophyte from semi-arid region was most abundant in closest distance from the street.

- Hypothesis no. 3: Does Atriplex tatarica presence affect other plant species?

We supposed that Tatarian orache as a weak competitor did not significantly decrease the abundance of other plant species regardless of $\mathrm{NaCl}$ concentration and distance from the road.

Field observations were carried out in Warsaw in July and August 2004. We recorded the presence of $A$. tatarica patches along $973 \mathrm{~km}$ of the roadsides in the city of Warsaw. We investigated roadside lawns along all main streets sprayed with salt during snow season and also many secondary streets with no salt de-icing.

In order to test hypothesis no. 1 we compared our results to data from the earlier study of Sudnik-Wójcikowska (1987). In 1977-1982 she recorded the distribution of Atriplex tatarica in Warsaw and found the species in $31 \%$ of fields of the rectangular grid, covering the whole area of Warsaw (Fig. 1A). We used two independent methods of comparison: the sign test and the test for proportions (Sokal and Rohlf 1995). We intersected our map of Atriplex tatarica patches with the Sudnik-Wójcikowska grid (1987) and compared the numbers of squares, where the species was present and absent in 1977-1982 and in 2004. We also calculated the ratio of roadside length covered by A. tatarica patches to total screened roadside length in different districts of the city, in order to find patterns of Tatarian orache distribution depending on the localization in the city (centre-suburbs, South-North, West and East side of the Vistula River).

In order to test hypothesis no. 2 we set up 50 research plots ( $25 \mathrm{~m}$ long, $1.5 \mathrm{~m}$ wide, divided into squares $0.5 \times 0.5$ $\mathrm{m})$ located on roadside lawns in various parts of the city. At each research plot we set five transects across the roadside lawn, located every 5 meters along the road. Each transect consisted of three $0.5 \times 0.5 \mathrm{~m}$ squares establishing three zones: $0-0.5 \mathrm{~m}$ from the roadside curb (area closest to the road), 0.5-1 $\mathrm{m}$ from the curb (intermediate zone) and 1$1.5 \mathrm{~m}$ from the curb (the most distant zone). In each square we estimated the percentage cover of $A$. tatarica. In each square we took soil samples in order to measure $\mathrm{NaCl}$ concentration $\left(\mathrm{g} / \mathrm{dm}^{3}\right)$ with the Conductivity Meter Type CC103 with automatic temperature compensation. Altogether we analysed $5960.5 \times 0.5 \mathrm{~m}$ squares from all of the research plots. The relationships between A.tatarica cover, $\mathrm{NaCl}$ concentration and the distance from the road was analysed using Analysis of Variance. Tukey post-hoc test for multiple comparisons was used to calculate differences between the means. We also calculated coefficients of variation for $\mathrm{NaCl}$ concentration in each of three zones (Sokal and Rohlf 1995). In order to assess the relative importance of salinity and the distance from the road we used the Multiple Linear Regression model with A.tatarica cover as a dependent variable and $\mathrm{NaCl}$ concentration and distance as independent variables.

In order to test hypothesis no. 3, we estimated the overall cover of other plant species, and compared the mean of other plants cover in absence and presence of A. tatarica. In order to separate the effect of A. tatarica from the effects of the distance from the road and the $\mathrm{NaCl}$ concentration we divided the data set into six subsets, with the use of natural breaks based on the $\mathrm{K}$-means clustering. $\mathrm{NaCl}$ concentration values were divided into two classes and the distance from the road - into three classes. For each subset we assessed the significance of the difference with the t-Student's test for unequal variances (Sokal and Rohlf 1995).

Statistical analyses were performed using SAS/STAT ${ }^{\circledR}$ software (2002-2003) and R-project ver. 2.9.2 (R Development Core Team 2009) with package rattle version 2.5.5.

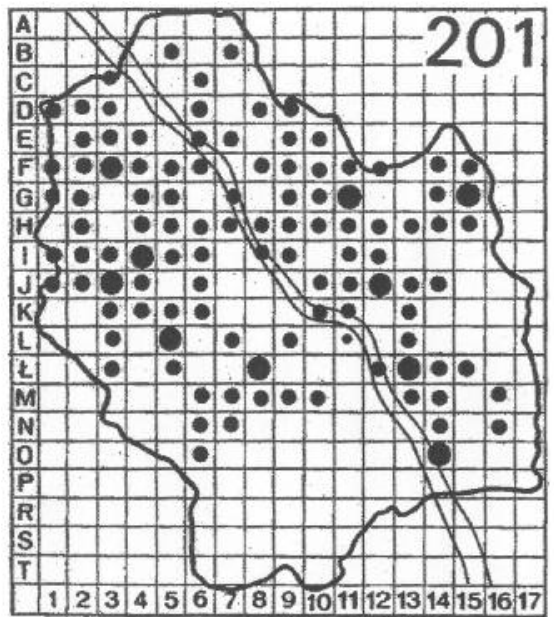

A

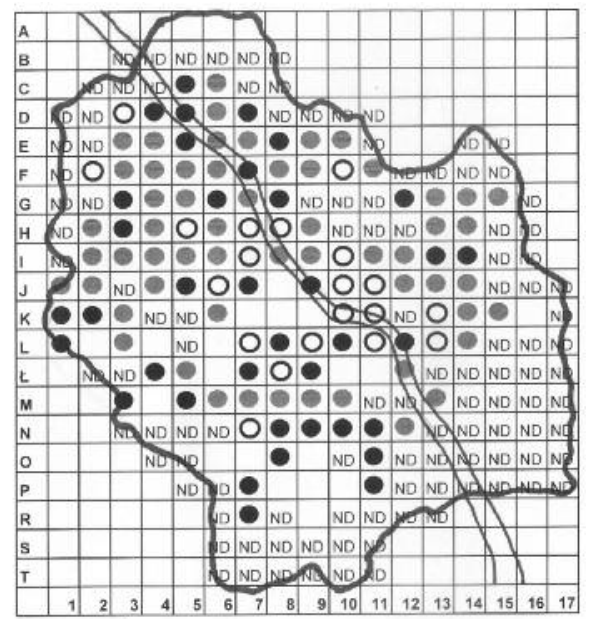

B
Fig. 1. Changes in distribution of Atriplex tatarica in the area of Warsaw at the square grid with the side of $1.5 \mathrm{~km}$. A - places recorded by Sudnik-Wójcikowska in 1977-1982; B - places recorded in 2004. Position of Vistula River is also drawn.

The legend for part $\mathrm{B}$ of the figure: grey circle - no changes, species present in 2004 and in 1977-1982; black circle - new stand, species present in 2004, while not recorded in 1977-1982; empty circle - stand disappeared, species not recorded in 2004, while present in 1977-1982; empty square within the borders of the city - species not recorded at all; ND - not determined in 2004. 


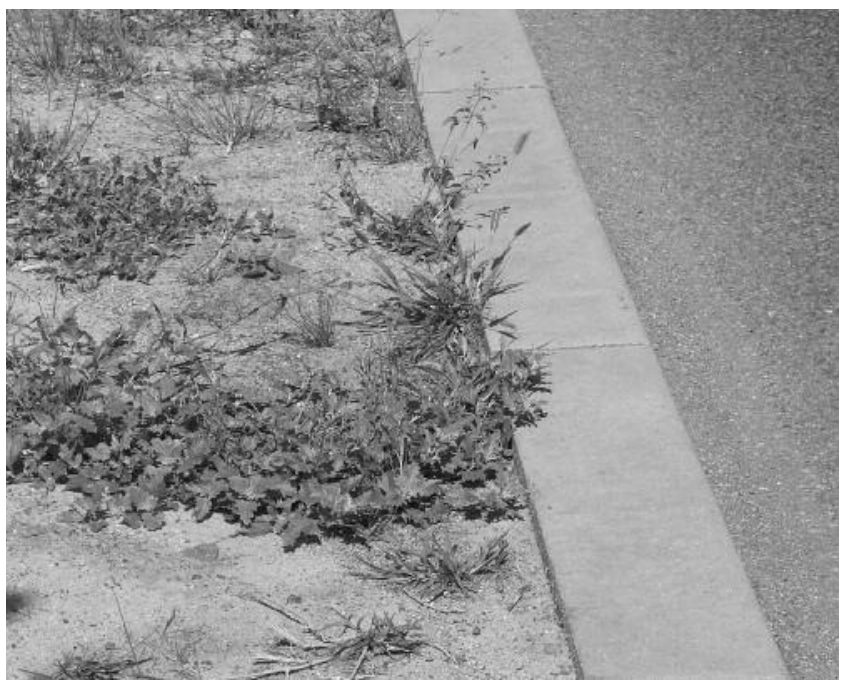

Fig. 2. Atriplex tatarica grows in patches on roadside lawns in the zone closest to the street verge. Picture taken in July 2009 at Puławska street, one of the main streets in Warsaw.

\section{RESULTS}

\section{Changes of distribution of Atriplex tatarica} in the city of Warsaw during last decades (Fig. 1).

We recorded the presence of $A$. tatarica in 92 squares $(41 \%)$, which is significantly more than recorded by $\mathrm{Su}-$ dnik-Wójcikowska (1987) about 25 years earlier (Fig. 1A) (the test for proportions, $\mathrm{P}<0.05$ ). Also the sign test showed, that there are significantly more new squares with $A$. tatarica, than squares, where species disappeared (36 squares vs 20 squares, $\mathrm{P}<0.05$, two sided test). Distribution of A. tatarica in the area of Warsaw has visibly changed over the last 25 years (Fig. 1B). We found many new localizations of $A$. tatarica, especially along highroads in the suburbs, while at the centre of the city there are much less places with $A$. tatarica plants than before. We noted that the species grows in monodominant patches of different length (from few centimetres to $3 \mathrm{~km}$ ) along the streets (Fig. 2).
The species seems to be almost completely limited to the roadside lawns along the streets sprayed with salt and presumably does not appear along the side streets with no salt de-icing.

We also found that the ratio of roadside lawn length with A. tatarica patches to total screened roadside lawn length differs in various parts of the city (Fig. 3). It is the smallest in the closest centre of the city (only $2 \%$ of the roadsides lawns with Tatarian orache patches) and in southern districts, while in the North districts is the biggest, average $24 \%$ of roadside lawn length, in some places even up to $42 \%$. Diversity of A. tatarica frequency is bigger at the left side of Vistula river (Warsaw upland) than at right side (Vistula river valley).

2. Patterns of distribution of $A$. tatarica individuals on the research plots at roadside lawns depending on the distance from the road (Table 1).

We found significant differences in means of A.tatarica cover and $\mathrm{NaCl}$ concentrations according to the distance from the road (Table 1).

Tatarian orache covered over $48 \%$ of the area closest to the road ( $0-0.5 \mathrm{~m}$ from the roadside curb), $33 \%$ of the area in the intermediate zone $(0.5-1 \mathrm{~m})$ and only $24 \%$ in the most distant zone (1-1.5 m). Mean cover of A. tatarica depended significantly on distance from the roadside verge (ANOVA $\mathrm{P}<0.0001)$ and all mean cover values differed significantly from each other at $\mathrm{P}<0.05$.

$\mathrm{NaCl}$ concentration at the research plots was a very variable parameter (value ranged from $0.16 \mathrm{~g} / \mathrm{dm}^{3}$ to 3.78 $\mathrm{g} / \mathrm{dm}^{3}$ ) with the highest mean values in the zone $0-0.5$ $\mathrm{m}\left(0.8 \mathrm{~g} / \mathrm{dm}^{3}\right)$, and slightly lower but significantly different values with increasing distance from the street (ANOVA $\mathrm{P}<0.02)$. Only the first $(0-0.5 \mathrm{~m})$ and last $(1-1.5 \mathrm{~m})$ means differed significantly from each other $(\mathrm{P}<0.05)$. Also coefficient of variation value was very high in all three zones.

Multiple Linear Regression model revealed that both Na$\mathrm{Cl}$ concentration and distance from the road were equally significant regressors (both with $\mathrm{P}<0.0001$ ).
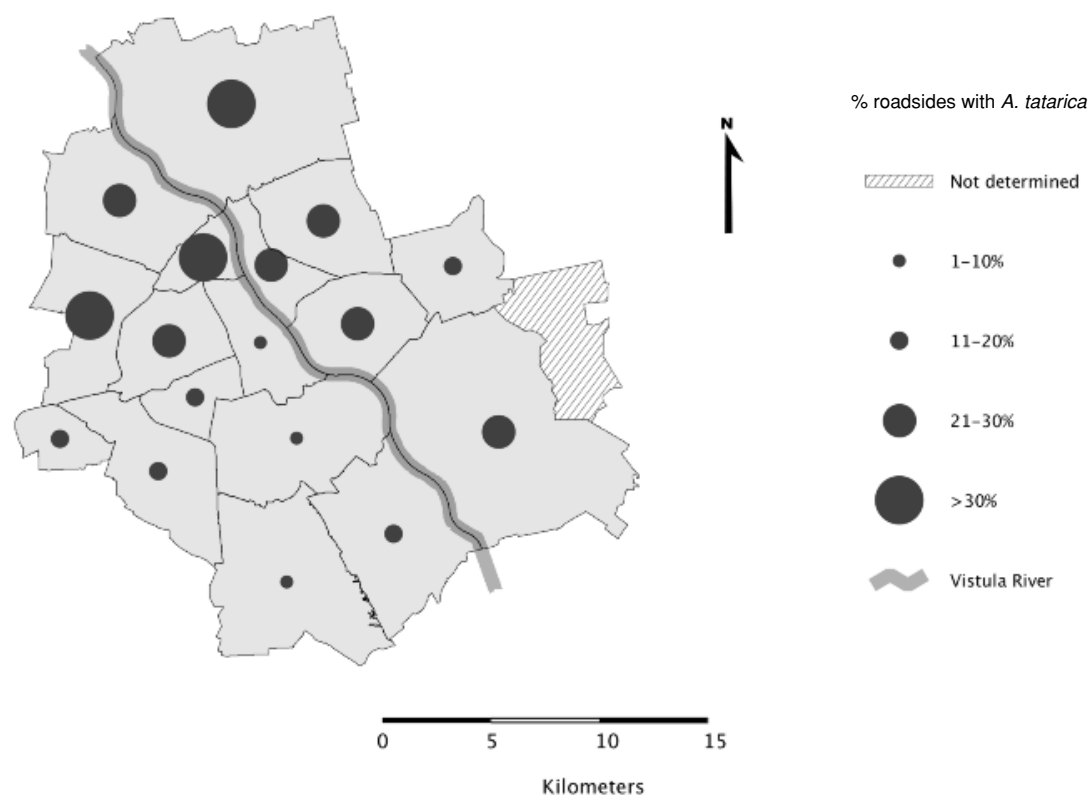

Fig. 3. Percentage ratio of roadside lawn lenght covered by Atriplex tatarica to total roadside lawn lenght recorded in our study in different districts of the city of Warsaw. 
TABLE 1. Changes of Atriplex tatarica and other species cover, $\mathrm{NaCl}$ concentration and also bare soil and litter cover with increasing distance from the roadside verge. Means with the same letter in the columns do not differ significantly at $\mathrm{P}<0.05$.

\begin{tabular}{|c|c|c|c|c|c|}
\hline $\begin{array}{c}\text { Distance } \\
\text { from the road verge }\end{array}$ & $\begin{array}{c}\mathrm{N} \\
\text { (sample size) }\end{array}$ & A. tatrica cover $(\%)$ & $\begin{array}{l}\text { Other plants cover } \\
\qquad(\%)\end{array}$ & $\begin{array}{l}\mathrm{NaCl} \text { concentration } \\
\left(\mathrm{g} / \mathrm{dm}^{3}\right)\end{array}$ & $\begin{array}{l}\text { Coeff. of variation } \\
\text { for } \mathrm{NaCl} \text { concentr. }\end{array}$ \\
\hline $0.00-0.50$ & 249 & $48.09 \mathrm{a}$ & $16.6 \mathrm{c}$ & $0.800 \mathrm{a}$ & 64.65 \\
\hline $0.51-1.00$ & 233 & $32.95 \mathrm{~b}$ & $36.53 \mathrm{~b}$ & $0.734 \mathrm{ab}$ & 59.37 \\
\hline $1.01-1.50$ & 111 & $23.84 \mathrm{c}$ & $48.77 \mathrm{a}$ & $0.657 \mathrm{~b}$ & 57.03 \\
\hline
\end{tabular}

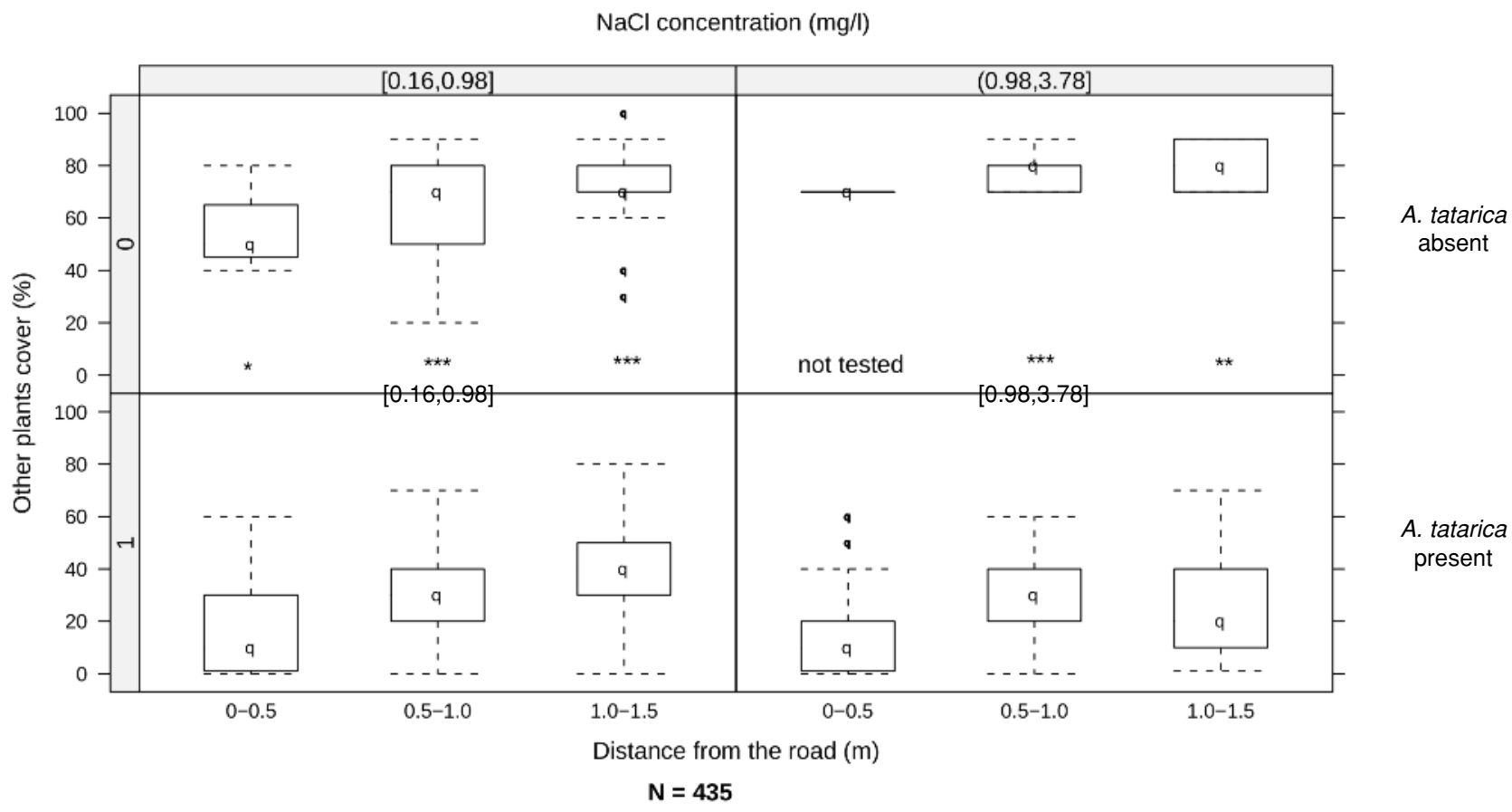

Fig. 4. Comparison of the value of mean other plants cover while Atriplex tatarica is present or absent in two NaCl level and three classes of the distance from the road. Signifiance of the difference was marked as follows: * $\mathrm{P}<0.05 ; * * \mathrm{P}<0.02 ; * * * \mathrm{P}<0.001$.

\section{Other plant covers}

in presence and in absence of A.tatarica

Apart from A. tatarica, there are other species at the roadside lawns, mainly grasses, i.e. Agropyron repens, Puccinellia distans, Poa annua, Lolium perenne, Poa pratensis, Digitaria sanguinalis, and other perennial (Taraxacum officinale), and annual species (Stellaria media, Lamium purpureum). Comparison of means of other plant covers in absence and in presence of $A$. tatarica in different $\mathrm{NaCl}$ levels (Fig. 4) gave significant differences in five of six subsets (in sixth subset we could not perform the test because the sample size was too small). In each case the other plant cover was higher in absence of $A$. tatarica.

\section{DISCUSSION}

Our results show that Atriplex tatarica increased significantly its overall spread at the roadsides in Warsaw (hypothesis no.1) during the last 30 years. Analysis of difference map (Fig. 1) may suggest that the species has settled new patches at the suburbs, probably along highroads. It may be caused by development of many peripheral districts with new roads and streets, which all need to be de-iced during the snow season. We also recorded the decrease of frequency of A. tatarica in the centre of the city. That may be simply the result of better care for urban greenery or the dramatic growth of building density in more fashionable districts of the capital of Poland.

The current frequency of Atriplex tatarica differs in various districts of the city, although the pattern is unclear. We have not found any dependence of A. tatarica frequency on its location within the city, i.e. inside or outside the urban-heat island, left or right side of Vistula river, and the location on the upland or in the river valley. This may suggest that the distribution of $A$. tatarica depends more on local factors. An important, promoting factor for this early successional species could be the regular roadside reconstruction practices. Roadside lawns are being renowned every couple of years due to soil compaction and contamination. This implies, that colonisation process of $A$. tatari$c a$ on many Warsaw roadsides may be forced to re-start every few years. We suppose that seed heterocarpy (Mandak et al. 2006) may be a big advantage of the species. Smaller, but long-term dormant, seed fraction may be the way to persist at the site during reconstruction, e.g by casual contact of former and new substrate layer. Big, winged, non dormant seeds should make quite long dispersal along the road possible, at least at the distance of few hundred meters, to the next suitable habitat patch.

\section{The role of the soil salinity and the distance from the road}

The persistence and even an increase of the frequency of halophytic species in the city is considered to be an effect 
of the deposition of salt during the winter road de-icing (Beaton and Dudley 2004; Leishman et al. 2004). It is estimated that approximately $15 \%$ of the salt used in de-icing is deposited on the roadside edge (Forman and Alexander 1998; Trombulak and Frissell 2000). The rest penetrates into the soil along with the rain and melting snow. $\mathrm{NaCl}$ concentration in the soil is higher in early spring than in summer or autumn after long-lasting rainfalls (Wrobel et al. 2006). Our soil samples were collected in the middle of the vegetation season. We still noticed a very high $\mathrm{NaCl}$ concentration on many research plots, even up to 3.78 $\mathrm{g} / \mathrm{dm}^{3}$. Mean $\mathrm{NaCl}$ concentration was slightly but significantly lower with greater distance from the street, which we had expected. This result is consistent with other authors (Wróbel et al. 2006), who also noticed a decreasing salinity with an increasing distance from the forest and field roads in Western Poland Lowland.

Our results showed that Tatarian orache grew mainly in the zone closest to the street verge (hypothesis no. 2), where the mean $\mathrm{NaCl}$ concentration was the highest. That may imply, that the species colonize most disturbed, probably empty places, because of the low competitive ability of the species (Kochankova and Mandak 2008). However, we detected a very high variability of salt concentration at every distance from the road - coefficients of variation were very high with all three distances. It means that roadside lawns form a mosaic rather than linear gradient habitat pattern in Warsaw. Every patch in this mosaic may have different combination of salinity and distance from the road verge. The analysis of the dependence of the A.tatarica cover on the distance from the road and the salinity (Multiple Linear Regression model) indicated that the proliferation of the species is equally related to both factors. The halophytic species grows more abundantly in the street-verge neighbourhood with the highest salinity level. While the intensity of salt deposition during winter road maintenance did not increase in recent years, there was a dramatic increase of the road traffic (Ben-Elia 2009), which may have been an important factor, responsible for the recent expansion of this invasive species during the last 30 years.

\section{Atriplex tatarica and other plants}

Our results contradict our expectations stated in hypothesis no. 3, based on literature reports on weak competitiveness of the species. Kochankova and Mandak (2008) described Atriplex tatarica as a weak competitor, occuring in open habitats where competitive pressure of other plant species is reduced to a minimum. They noticed that the species disappeared quickly from sites older than three years after disturbance, as perennials invaded the stand and out-competed this annual species. Kenkel et al. (1991) hypothesised, that there may be a reciprocal relationship between the salt tolerance of species and their competitive ability.

While we did not measure the intensity of competition directly in the field, the results of comparison of other plants cover in presence and in the absence of $A$. tatarica indicates that the species affects the other plants quite strongly. The cover of other plants was a few dozen percents higher when Tatarian orache was absent. However, many studies report, that salt tolerant species are less competitive only at lower salinities (Bertness et al. 1992; Alison 1996; Todd and Ungar 2001). We observed a lowered abundance of other species in all tested combinations of salinity and the distance from the road.

The next reason of quite good performance of A. tatarica on the roadside lawns in big cities may be the fact that it is a species with the $\mathrm{C} 4$ pathway of $\mathrm{CO}_{2}$ fixation (Kochankova and Mandak 2008). C4 plants are usually distributed in sub-tropical or tropical climates, where temperatures exceed the crossover temperature for photosynthetic efficiency (Osborne and Beerling 2006). C4 plants are better adapted than $\mathrm{C} 3$ plants also in an urban environment with high daytime temperatures, intense sunlight, and drought so they can produce biomass much faster. Although we did not prove any dependence of the species frequency on urbanheat island, we may expect that $A$. tatarica has some advantages over other $\mathrm{C} 3$ species growing on roadside lawns. Authors observed very fast growth of the species during summer season, which supports this thesis.

\section{LITERATURE CITED}

AKBAR K.F, HALE W.H.G, HEADLEY A.D.D. 2008. Floristic composition and environmental determinants of roadside vegetation in North England. Pol. J. Ecol. 57:73-88.

ALLISON S.K. 1996. Recruitment and establishment of salt marsh plants following disturbance by flooding. Am. Midl. Nat. 136: 232-247.

BEATON L.L, DUDLEY S.A. 2004. Tolerance to salinity and manganese in three common roadside species. Int. J. Plant Sci. 165:37-51.

BEN-ELIA E. 2009. Pricing in road transport. A multi disciplinary perspective. J. Transp. Geogr. 17: 318-319.

BERTNESS M.D., GOUGH L., SHUMWAY S.W. 1992. Salt tolerance and the distribution of fugitive salt marsh plants. Ecology 73: 1842-1851.

eFloras 2009. Flora of China,Vol. 5 Page 365. Published in the Internet http://www.efloras.org [accessed 26 October 2009] Missouri Botanical Garden, St. Louis, MO \& Harvard University Herbaria, Cambridge, MA.

FORMAN R.T.T., ALEXANDER L.E. 1998. Roads and their major ecological effects. Annu. Rev. Ecol. Syst. 29: 207-231.

GELBARD J.L., BELNAP J. 2003. Roads as conduits for exotic plant invasions in semiarid landscape. Conserv. Biol. 17: 420$-432$.

HAAL M.L., SURJE P. 2006. Environmental problems related to winter traffic safety conditions. Balt. J. Road Bridge E. 1: 45$-53$.

HASEGAWA P.M., BRESSAN R.A., ZHU J.K., BOHNERT H.J. 2000. Plant cellular and molecular responses to high salinity. Annu. Rev. Plant Phys. 51: 463-499.

KENKEL N.C., MCILRAITH A.L., BURCHILL C.A., JONES G. 1991. Competition and response of three plant species to a salinity gradient. Can. J. Bot. 69: 2497-2502.

KOCHANKOVA J., MANDAK B. 2008. Biological flora of Central Europe. Perspect. Plant Ecol. 10: 217-229.

LEISHMAN M.R., HUGHES M.T., GORE D.B. 2004. Soil phosphorus enhancement below stormwater outlets in urban bushland: spatial and temporal changes and the relationship with invasive plants. Aust. J. Soil Res. 42: 197-202.

LEUNG G.P.C., HAU B.C.H., CORLETT R.T. 2009. Exotic plant invasion in the highly degraded upland landscape of Hong Kong, China. Biodivers. Conserv. 18: 191-202.

MANDAK B. 2003. Germination requirements of invasive and non-invasive Atriplex species: a comparative study. Flora 198, 45-54.

MANDAK B., BIMOVA K., MAHELKA V., PLACKOVA I. 2006. How much genetic variation is stored in the seed bank? 
A study of Atriplex tatarica (Chenopodiaceae). Mol. Ecol. 15: 2653-2663.

OSBORNE C.P., BEERLING D.J. 2006. Nature's green revolution: the remarkable evolutionary rise of $\mathrm{C} 4$ plants. Phil. Trans. R. Soc. B 361 no. 1465:173-194; doi:10.1098/rstb. 2005.1737 [accessed 11 December 2009].

PYSEK P., SADLO J., MANDAK B. 2002. Catalogue of alien plants of the Czech Republic. Preslia 74: 97-186.

R DEVELOPMENT CORE TEAM (2009). R: A language and environment for statistical computing. R Foundation for Statistical Computing, Vienna, Austria. ISBN 3-900051-07-0, URL http://www.R-project.org.

SOKAL R.R., ROHLF F.J. 1995. Biometry: the principles and practice of statistics in biological research. 3rd edition. W. H. Freeman and Co., New York, pp. 887.

SUDNIK-WÓJCIKOWSKA B. 1987. Flora miasta Warszawy i jej przemiany w ciągu XIX i XX wieku. Wydawnictwa UW, Warszawa. (in Polish)
SAS/STAT software, Version 9.1 of the SAS System for Windows. Copyright (c) 2002-2003 by SAS Institute Inc., Cary, NC, USA.

TODD P.E., UNGAR I.A. 2001. Competition between Salicornia europaea and Atriplex prostrata (Chenopodiaceae) along an experimental salinity gradient. Wetl. Ecol. Manag. 9: 457-461.

TROMBULAK S.C., FRISSELL C.A. 2000. Reviev of ecological effects of roads on terrestrial and aquatic communities. Conserv. Biol. 14: 18-30.

UNGAR I.A. 1996. Effect of salinity on seed germination, growth, and ion accumulation of Atriplex patula (Chenopodiaceae). Am. J. Bot. 83(5): 604-607.

WRÓBEL M., TOMASZEWICZ T., CHUDECKA J. 2006. Floristic diversity and spatial distribution of roadside halophytes along forest and field roads in Szczecin lowland (Western Poland). Pol. J. Ecol. 54: 303-309. 